\title{
Effect of Black Walnut (Tetracarpidium conophorum) Leaf Extract on the Reproductive Organ of Male Albino Rats
}

\section{Ojobor Charles Chijioke*, Anosike Chioma Assumpta, Ezeanyika Lawrence Uchenna Sunday}

Department of Biochemistry, University of Nigeria, Nsukka, Nigeria

\author{
Email address: \\ charlidon4real@yahoo.com (O.C. Chijioke) \\ ${ }^{*}$ Corresponding author
}

\section{To cite this article:}

Ojobor Charles Chijioke, Anosike Chioma Assumpta, Ezeanyika Lawrence Uchenna Sunday. Effect of Black Walnut (Tetracarpidium conophorum) Leaf Extract on the Reproductive Organ of Male Albino Rats. International Journal of Homeopathy \& Natural Medicines. Vol. 3, No. 1, 2017, pp. 9-14. doi: 10.11648/j.ijhnm.20170301.12

Received: May 19, 2017; Accepted: June 23, 2017; Published: October 18, 2017

\begin{abstract}
This study determined the effect of Tetracarpidium conophorum (black walnut) leaf extract on the male reproductive organs of albino rats. The effects of the leaf extracts were determined on the Epididymal sperm concentration, Testicular histology, and on testosterone concentration in the rat serum by a micro plate enzyme immunoassay (Testosterone assay). A total of sixteen (16) male albino wistar rats were divided into four (1, 2, 3 and 4) groups of four rats each. Group 1 served as the control and was fed with normal diet only, while groups 2, 3 and 4 were fed with 200,400 and $600 \mathrm{mg} / \mathrm{kg}$ body weight (BW) of the extract for a period of two weeks. The Epididymal sperm concentration were not significantly affected $(\mathrm{p}>0.05)$ across the groups. The level of testosterone for the treatment groups 2 and 4 showed no significant difference $(\mathrm{p}>0.05)$ compared to the control while group 4 showed significant increase compared to that of the control $(\mathrm{p}<0.05)$. Pathologic changes were observed in testicular histology across the treatment groups. Robust seminiferous tubular lumen containing sperm cells and increased production of Leydig cells and Sertoli cells were observed across different treatment groups compared to that of the control.
\end{abstract}

Keywords: Tetracarpidium conophorum, Sperm, Male Reproductive Organ, Testicular Histology, Rats

\section{Introduction}

Tetracarpidium conophorum otherwise known as Black walnut belongs to the genus juglans, family juglandaceae and has been widely used in traditional medicine throughout the world [1]. Walnut comprises such families as Juglandaceae (English walnut), Euphorbiaceae and Olacaceae (Black walnut). Tetracarpidium conophorumis an economic plant widely cultivated for the production of nuts and is used as delicacies [2]. The English walnuts are called Juglan regia while the black walnuts are known as Juglans nigra. Black walnut is known in the Eeasthern Nigeria (Igbo) as ukpa, Western Nigeria (Yoruba) as awusa or asala and Northern Nigeria (Hausa) as gawudi bairi and it is cultivated principally for its nuts which are cooked and consumed.

Studies have shown that walnut kernels are used to reduce blood lipids, increase high density lipoprotein and reduce low density lipoprotein [3], [4]. Walnut is also effective in the treatment of type-2 diabetes and enhancing cardiovascular flexibility [5]. The leaf extract of $\mathrm{T}$. conophorum have been reported to possess antibacterial and antifungal activities [6]. The root extract of the plant also displays antibacterial activity as reported by [6]. Walnuts extract possess anticancer property and reduce diabetic complications [6]. The presence of oxalates, phytates, tannins as well as proteins, fibres, oil and carbohydrate in Tetracarpidium conophorum has been reported [7]. The phytochemical and nutrient evaluation of Tetracarpidium conophorum (Nigerian walnut) root has also been reported [8].

Though the nuts are generally eaten in Nigeria, much work has not been reported on the effect of the leaves on the male reproductive organ within the locality and state covered in this report. Therefore, the objective of this work was therefore to evaluate the effect of walnut leaf extract on male reproductive organ of albino rats. 


\section{Materials and Methods}

\subsection{Animal}

Sixteen (16) adult male Wister albino rats (8-14 weeks) of average weight of $100-120 \mathrm{~g}$ were obtained from the animal house of the Faculty of Biological Sciences, University of Nigeria, Nsukka. The animals were acclimatized for 7 days under standard laboratory conditions with a 12 hour light/dark cycle maintained on a regular feed and water. They were randomly divided into four groups of four rats each.

Group I (Control): rats fed normal diet water and $0.5 \mathrm{ml}$ Tween 80 for two weeks.

Group II: rats administered low dose $(200 \mathrm{mg} / \mathrm{kg} \mathrm{BW})$ of the leaf extract.

Group III: rats administered medium dose $(400 \mathrm{mg} / \mathrm{kg} \mathrm{BW})$ of the leaf extract.

Group IV: rats administered high dose $(600 \mathrm{mg} / \mathrm{kg} \mathrm{BW})$ of the leaf extract.

\subsection{Plant Material}

Healthy walnut leaves were obtained from the environs of Ibagwa, Igbo Eze South L.G.A., Enugu State, Nigeria. The leaves were identified and authenticated in the Department of Plant Science and Biotechnology, University of Nigeria, Nsukka (UNN).

\subsection{Preparation of Plant Material}

The freshly collected leaves of Tetracarpidium conophorum were separated, dried, and milled into powder using a hand mill. The walnut leaf powder was soaked in methanol (1L) for $48 \mathrm{~h}$, filtered using No 1 Whatman filter paper and concentrated in rotary evaporator at $40^{\circ} \mathrm{C}$.

\subsection{Proximate Analysis}

The [9] method was used to determine the proximate constituents of Tetracarpidium conophorum. Moisture content was determined by drying to constant weight at 60 $80^{\circ} \mathrm{C}$ in an oven, ash content was determined by ignition at $550^{\circ} \mathrm{C}$ in a muffle furnace for $4 \mathrm{~h}$, oil content was by soxhlet extraction with hexane, protein was by the Kjeldahl method and crude fibre was by the acid and alkaline digestive methods. The carbohydrate content was estimated by difference, subtracting the sum of protein, fat and crude fibre percentages from one hundred.

\subsection{Blood Collection}

Blood was collected via the medial canthus of the eye with non-heparinized capillary tubes and centrifuged at 3000rpm for $15 \mathrm{~min}$.Serum obtained was pipetted into $2 \mathrm{ml}$ polypropylene tubes, and then stored at $-8^{\circ} \mathrm{C}$ until analysis. Frozen serum was allowed to thaw at room temperature prior to respective assays.

\subsection{Test Procedure for Testosterone}

Several wells for calibrators, control and the test samples were properly placed in duplicate. Calibrator, control and test samples $(50 \mu \mathrm{l}$ each) was added to the corresponding labeled wells in duplicate followed by addition of $100 \mu$ lof conjugate working solution. The resulting solution was properly mixed and incubated on a plate shaker (approximately 200rpm) for $60 \mathrm{~min}$ at room temperature. Each well was properly washed with $300 \mu 1$ of diluted washed buffer and the plate firmly tapped against absorbent paper to ensure that it was dry. Tetramethylbenzidine (TMB) substrate $(150 \mu l)$ was added to each well and incubated for $15 \mathrm{~min}$ at room temperature before the addition of $50 \mu 1$ stop solution. The absorbance was read at $450 \mathrm{~nm}$ within $20 \mathrm{~min}$ after addition of the stop solution using UV visible spectrometer [10].

\subsection{Preparation of the Epididymes}

After bleeding the animal to death, the epididymides were dissected out from the scrotal sac of each of the rats using scapel blade and scissors. The epididymis was kept on properly labeled test tube containing $10 \%$ formal saline.

\subsection{Epididymal Sperm Count Determination}

This was carried out according to the method of [11]. The epididymal content was obtained by macerating with fine scissors known weights of the caput and cauda epididymides in a glass petridish containing warmed buffered physiological saline in the ratio of $1: 1 \mathrm{w} / \mathrm{v}$. After vigorous pipetting, the suspension was separated from the tissue fragments by filtering it through $80 \mu \mathrm{m}$ stainless mesh. A tissue-free aliquot was loaded into the Neubauer haemocytometer. Five different counts were done for each sample, and the mean was taken as the mean count for each rat.

Sperm count $=$ Total number of sperm cells in the cytometer/Mean value

Where; mean value $=$ five .

\subsection{Determination of Testicular Histology}

Two rats from each group were sacrificed and their testicles dissected out. About $4 \mathrm{~mm}$ thick sections of each testis were fixed in $10 \%$ formal saline. The tissues were then dehydrated in ascending grades of alcohol followed by clearing in chloroform. They were thereafter embedded in paraffin, sectioned at 5micronseach using a rotary microtome.The cut sectioned were then stained using hematoxylin and Eeosin ( $\mathrm{H} \& \mathrm{E})$ stains, viewed under a light microscope and images captured with a motic camera[12].

\subsection{Statistical Analysis}

The results were expressed as mean \pm SD and test of statistical significance was carried out using one-way analysis of variance (ANOVA). The means were separated using Duncan multiple test. The statistical analysis was carried out using statistical package for social sciences (SPSS), version 20. Differences were considered significant at $\mathrm{p}<0.05$. 


\section{Results and Discussion}

Table 1. Result of Proximate Composition of walnut leaf extract

\begin{tabular}{ll}
\hline Proximate & Percentage Mean Composition \\
\hline Moisture (\%) & $53.40 \pm 0.00$ \\
Ash $(\%)$ & $0.66 \pm 0.08$ \\
Fats $(\%)$ & $12.81 \pm 0.01$ \\
Protein $(\%)$ & $8.76 \pm 0.03$ \\
Carbohydrate $(\%)$ & $24.36 \pm 0.04$ \\
Energy Value $(\mathrm{kcal})$ & $247.77 \pm 0.23$ \\
\hline
\end{tabular}

Each data is mean of three replicates \pm Standard Deviation (SD).

Table 1 showed the percentage proximate composition of the walnut leaf extract. These results were in agreement with earlier reports of proximate compositions of the seeds by [13, 8]. The moisture content is an important parameter as it affects the percentage yield of the seed oils during extraction [14]. This indicates why the walnut seed has low oil yield judging from high amount of its moisture content [15]. The fibre and protein contents of the plant show that it is nutritionally rich and also, could be regarded as a valuable source of dietary fibre in human nutrition. Adequate intake of dietary fibre can lower cholesterol level, risk of coronary heart diseases, hypertension, constipation, diabetes, colon and breast cancer $[16,17]$.

Result of testicular histological examination.

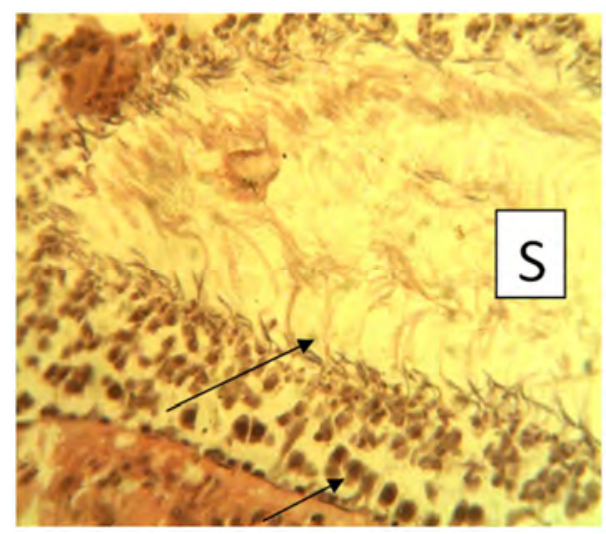

Figure 1. Photomicrograph of testis from control rats showing the seminiferous tubular lumen containing sperm cells (S) and prominent sertoli cells (arrows).

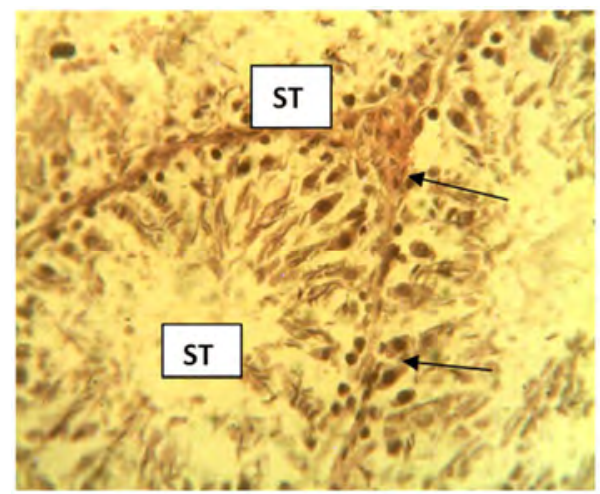

Figure 2. Histological section of testis from rats administered $200 \mathrm{mg} / \mathrm{kg}$ of methanol extract of walnut leaves showing scanty sperm cells in the serminiferous tubules (ST) with no observable histological changes.

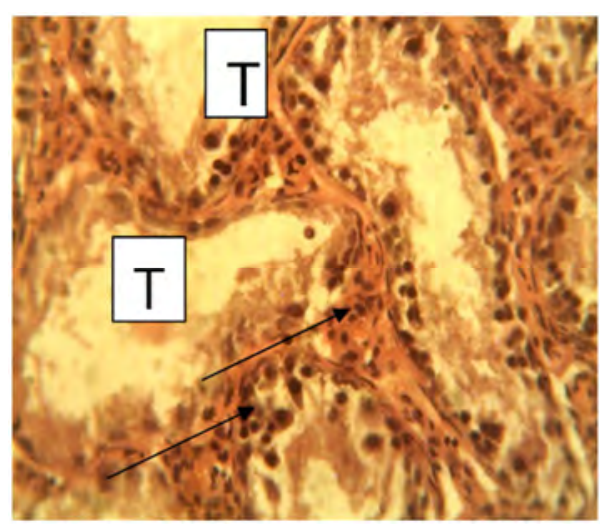

Figure 3. Photomicrograph of testis from rats adminstered with $400 \mathrm{mg} / \mathrm{kg}$ of methanol extract of walnut leaves showing the seminiferous tubules (T) and the interstitial connective tissues containing the leydig cells (arrows).

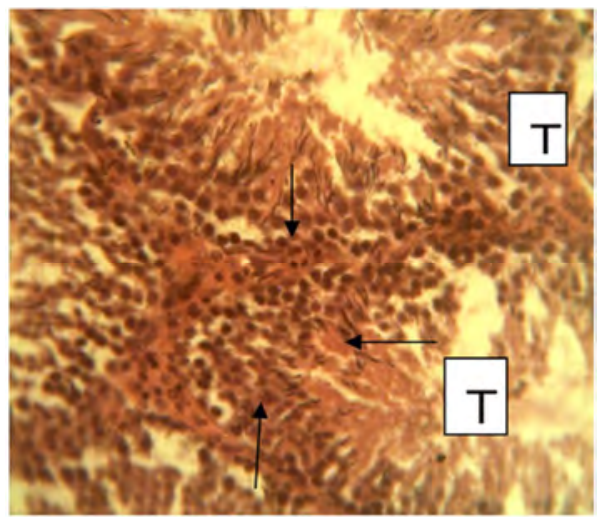

Figure 4. Photomicrograph of a section of testis from rats adminstered with $600 \mathrm{mg} / \mathrm{kg}$ of the extract showing a robust seminiferous tubules $(T)$, prominent leydig cells within the interstitium (arrows).

The results of the testicular histology of the treatment groups 3 and 4 showed observable histological changes compared to control (Figure 3 - 4). No histological effect was observed between treatment group 2 and the control (see figure 2). The testicular histology was observed to increase with increased concentration of walnut extract in the diet. The robust seminiferous tubular lumen containing sperm cells and prominent leydig cells observed across the treatment groups 3 and 4 indicates why there was a significant increase $(\mathrm{p}<0.05)$ of testosterone level in rats administered with $600 \mathrm{mg} / \mathrm{kg}$ (Figure 4 ) which also indicates that the effect of the walnut extract on the reproductive health of male rats was dose-dependent. The effect may be comparable with the findings by [10], which reported that, the effect of seed powder of T. conophorum on male albino rat sex hormones was dose-dependent. Though the leaf extract of $\mathrm{T}$. conophorum did not show significant effect on the testosterone level, there were observed differences on the sperm viability among the rats in the different groups which could be attributed to the abundant amount of vitamin $\mathrm{E}$ and zinc present in the extract, which are known male fertility agents as reported by [6]. The seeds of T. conophorum have been reported to contain reasonable amounts of zinc and vitamin $\mathrm{E}[8,15]$. However, the observed effect of the walnut on the level of testosterone was in accordance with the trend 
observed in the testicular histopathology. This is because testes are responsible for making testosterone, the primary male sex hormone, and for generating sperm. Within the testes are coiled masses of tubes called seminiferous tubules. These tubes are responsible for producing sperm cells. Sertoli cells from the walls of seminiferous tubules. The cells nourish, support and protect developing germ cells, which undergo cell division by meiosis to form spermatozoa (immature sperm).

Table 2. Result of testosterone and epididymal concentration.

\begin{tabular}{lll}
\hline Groups & Mean \pm SD & \\
\hline & Testosterone $(\mathbf{n g} / \mathbf{d l})$ & Epididymis $(\times \mathbf{1 0} / \mathbf{m l})$ \\
\hline GROUP1 & $0.37 \pm 0.33$ & $219.33 \pm 30.86$ \\
(CONTROL) & & \\
GROUP2 (200mg) & $0.97 \pm 0.13$ & $215.00 \pm 36.29$ \\
GROUP3 (400mg) & $0.87 \pm 0.66$ & $226.00 \pm 17.06$ \\
GROUP4 (600mg) & $2.20 \pm 1.31$ & $233.00 \pm 8.19$ \\
\hline
\end{tabular}

Each data is mean of three replicates \pm Standard Deviation (SD).

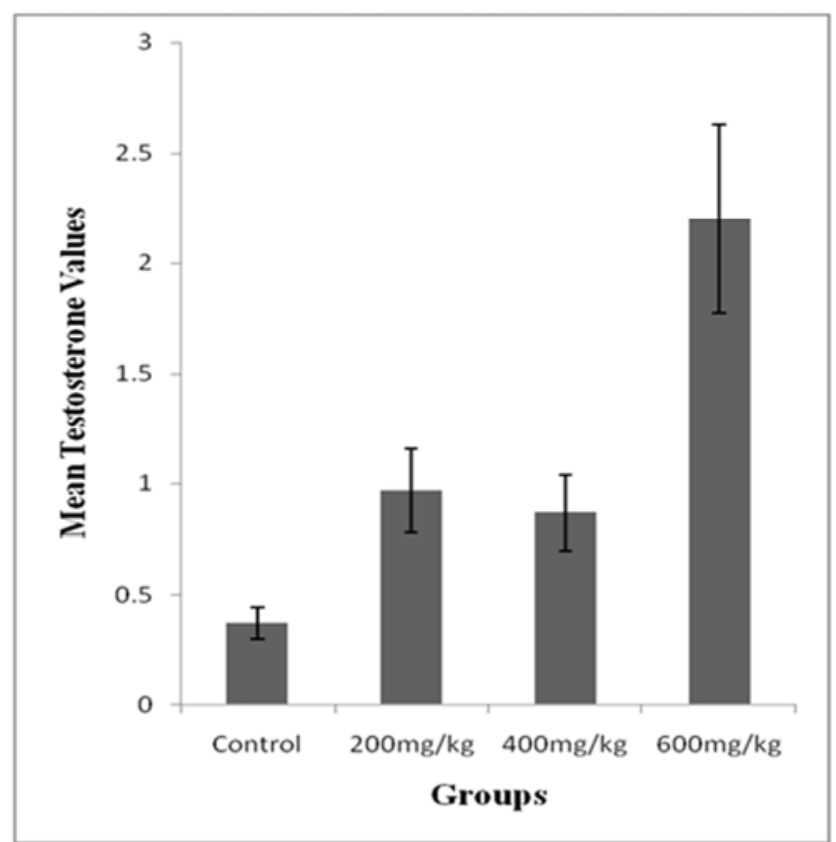

Figure 5. Effect of methanol extract of walnut leaves on testosterone levels in rats.

The results as shown in (Table 2 and Figure 5) showed that testosterone level for the treatment group 2 had no significant difference $(p>0.05)$ compared to that of the control while group 4 showed non-significant increase compared to that of the control $(p<0.05)$. The trends observed from the experimental groups show that the influence of the test extract on the level of testosterone was dose dependent. According to the results of this research, the increase in testosterone level suggests a positive effect of walnut on pituitary - testicular axis. The hypothalamus-pituitarytesticular axis can be affected by various negative and positive feedbacks. Nitric oxide (NO) is one of the factors affecting this axis [1]. High levels of Arginine in walnut can be converted to nitric oxide. Nitric oxide increases the release of gonadotropin-releasing hormone $(\mathrm{GnRH})$, which in turn increases gonadotropin secretion by activating neuron nitric oxide synthase enzyme in the pituitary gland [18, 19]. Nitric oxide activates Guanylate cyclase enzyme that causes the release of cyclic guanosine monophosphate and eventually by raising gonadotropin - releasing hormone (GnRH), luteinizing hormone ( $\mathrm{LH})$ and follicle - stimulating hormone (FSH), enhances sperm motility and induces erection in males [20]. Reports have also shown that there are other amino acids (including aspartic acid)that regulate the synthesis of testosterone via cyclic guanosine monophosphate (cGMP), and cyclic adenosine mono-phosphate (cAMP) as these messengers in pituitary and testes, respectively [21, 1]. Earlier study also indicated that an increased testosterone level had been the secondary consequence of increased gonadotropin-releasing hormone $(\mathrm{GnRH})$, particularly the luteinizing hormone (LH). Walnuts contain a large amount of polyunsaturated fatty acids such as linolenic acid, linoleic acid and oleic acid [22]. However, it appears that the increase in testosterone levels with walnut leaf extract was due to its direct effect on Leydig cells, as well as its interference with the biosynthesis of testosterone which was probably through stimulating the synthesis of prostaglandins series [1]. Walnut kernels contain alphalinolenic acid, which can be converted to arachidonic acid, as a precursor for the synthesis of type- 2 prostaglandins such as E2 [23].

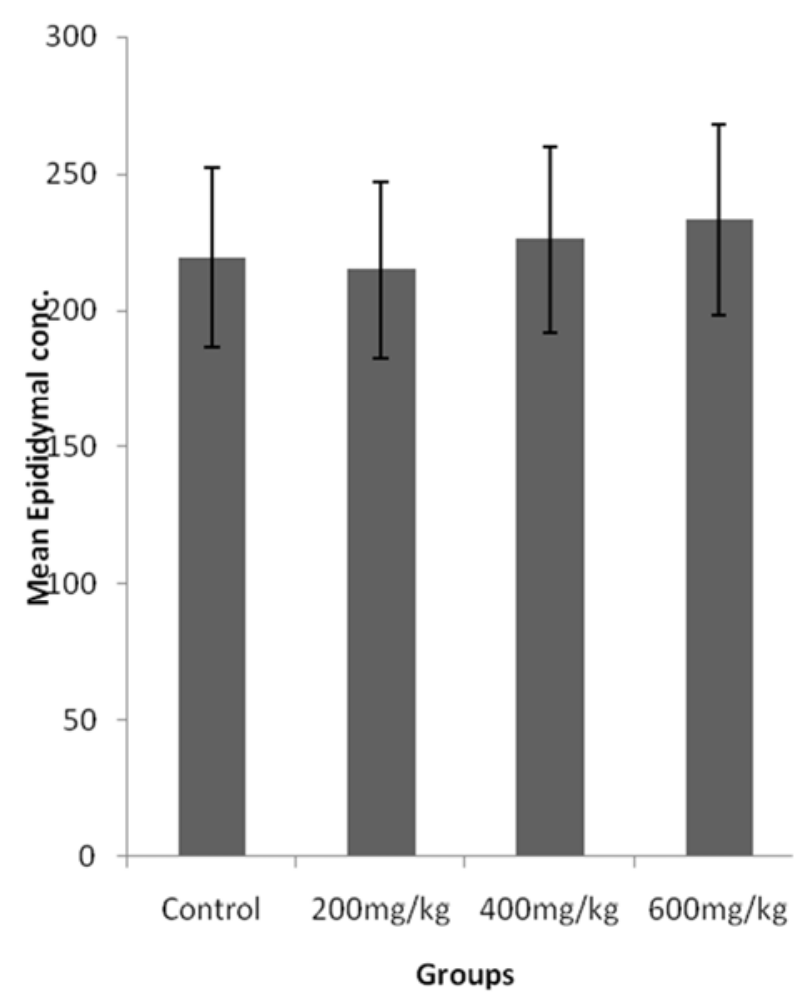

Figure 6. Effect of methanol extract of walnut leaves on epididymis concentration.

Results of effect of the extract of walnut leaves on epididymis concentration epididymis concentration are shown in Table 2 and Figure 6. The epididymis is a complex 
organ, where the immotile and infertile spermatozoa leaving the testis acquire both their motility and fertility. It rests on the backside of each testicle. Its main function is to transport and store sperm cells that are produced in the testes to bring them to maturity, since the sperm that emerge from the testes are immature and incapable of fertilization. In sexually mature rats, the paired cauda epididymis contains approximately $440 \times 10^{6} / \mathrm{ml}$ spermatozoa [24]. In the present study, the concentration of spermatozoa in the cauda epididymis of the adult wistar rats was found to be $219.33 \pm 30.86 \times 10^{6} / \mathrm{ml}$ in group $1,215.00 \pm 36.29 \times 10^{6} / \mathrm{ml}$ in group 2, $226 \pm 17.06 \times 10^{6} / \mathrm{ml}$ in group 3 and $233 \pm 8.19 \times 10^{6} / \mathrm{ml}$ in group 4 respectively. These values were close to the values reported for Sprague Dawley albino rats by [25], who detected $1 \cdot 84( \pm 0 \cdot 10 \mathrm{SEM}) \times 10^{9}$ spermatozoa/ml in the cauda epididymidis of adult animals, using a micropuncture technique. Though the method applied here is simple and unsophisticated, it is precise and reproducible. However, it might be useful in studies concerning not only normal epididymal function but also factors affecting the production of spermatozoa in the testis and/or their storage and resorption in the cauda epididymidis.

\section{Conclusion}

Dietary habits and essential nutrients to promote successful reproductive outcomes have been identified for the maternal periconceptional and perinatal period [26], but healthy dietary and essential nutrients for paternal reproductive fitness are less clear.

The present study investigated the percentage proximate compositions of Tetracarpidium conophorum (Nigerian walnut) leaves and effect of the leaf extract on male reproductive organ of albino rats. This shows the use of the leaves of this plant in human and animal nutrition and also in herbal medicine. The trends observed from the experimental groups suggest that the influence of the plant extract on the level of testosterone was dose dependent. Though there were no significant effect observed between treatment group 2 and that of the control, it was established that the sample extract of $\mathrm{T}$. conophorum has effect on the reproductive pathways of the rats. This is because of the observed significant increase in the concentration of the testosterone level in the treatment group 4, and the testicular histopathology shown to be well preserved across the treatment groups. This research suggests a potential for the incorporation of the leaves in the formulation of male fertility drugs. Further studies have to be carried out to isolate, characterize and elucidate the structure of the bioactive compounds from the whole parts of Tetracarpidium conophorum.

\section{References}

[1] Motahareh, B., Haidar, A., Seyed, E. H. and Saeed, C. A. (2014). A study on the effect of walnut oil on plasma levels of testosterone pre and post puberty in male rats. American Journal of Ethnomedicine, 1(4): 266-275.
[2] Adebona M. B., Ogunsua A. O., Ologunde M. O., 1988. Development of conophor nut-based cereal snack food IBiscuits. Journal of Food and Agriculture, 2: 123-136.

[3] Iwamoto, M., Imaizumi, K., Sato, M., Hirooka, Y., Sakai, K., Takeshita, A. (2002). Serum lipid profiles in Japanese women and men during consumption of walnuts. European Journal of Clinical Nutrition, 56(7): 629-37.

[4] Tavakoli, Darestani A., Kimiagar, S. M., Velaei, N. (2005). Persian Walnut effect on serum lipids in postmenopausal women. Journal of Mazandaran University of Medical Sciences, 14(44): 21-32.

[5] Tapsell, L. C., Batterham, M. J., Teuss, G., Tan, S. Y., Dalton, S., Quick, C. J. (2009). Long-term effects of increased dietary polyunsaturated fat from walnuts on metabolic parametersin type II diabetes. European Journal of Clinical Nutrition, 63(8): 1008-1015.

[6] Ajaiyeoba, E. O. and Fadare, D. A. (2006). Antimicrobial potential of extracts and fractions of the African walnut Tetracarpidium conophorum. African Journal of Biotechnology, 5(22): 2322-5.

[7] Enujiugha, V. N. and Ayodele-Oni, O. (2003). Evaluation of nutrients and some anti-nutrients in lesser-known, underutilized oilseeds. International Journal of Food Science and Technology, 38(5): 525-528.

[8] Ayoola, P. B., Onawumi, O. O. and Faboya, O. O. P. (2011). Chemical evaluation and nutritive values of Tetracarpidium conophorum (Nigerian walnut) seeds. Journal of Pharmaceutical and Biomedical Sciences, Vol. 11(15).

[9] AOAC (1990). Official method of analysis $15^{\text {th }}$ Edn. Association of Official Analytical Chemist, Washington D. C. 1: pp. 600-792.

[10] Ikpeme, E. V., Ekaluo, U. B., Udensi, O., Ekerette, E. E., Ekpo, P. B. and Asuquo, B. O. (2014). Sperm quality and hormone profile of male albino rats fed with Seeds of African walnut (Tetracarpidium conophorum, Mull). Annual Research \& Review in Biology, 4(9): 1379-1386.

[11] Ekaluo, U. B., Ikpeme, E. V. and Udokpoh, A. E. (2009). Sperm Head Abnormality and Mutagenic Effects of Aspirin, Paracetamol and Caffeine Containing Analgesics in Rats. The Internet Journal of Toxicology. 7(1): 1-9.

[12] Anosike, C. A., Ezeanyika, L. U. S. Obidoa, O. (2007). Effect of roasted soyabean (Glycine max) diet on the histology of selected rat tissues. Bio-Research, 5(2): 237-240.

[13] Okwu, D. E. (2004). Phytochemical and vitamin content of indigenous spices of South Eastern Nigeria. Journal of Sustainable Agriculture and Environment, 1: 30-37.

[14] Mansor, T. S. T., Che Man, Y. B., Shuhaimi, M., Abdul Afiq, M. J. and Ku Nurul, F. K. M. (2012). Physicochemical properties of virgin coconut oil extracted from different processing methods. International Food Research Journal, 19(3): 837-845.

[15] Ojobor, C. C., Anosike, C. A. and Ani, C. C. (2015). Studies on the phytochemical and nutritional properties of Tetracarpidium conophorum (Black walnut) seeds, Journal of Global Biosciences, Vol. 4(2), 1366-1372.

[16] Rao, C. V. and Newmark, H. L. and Reddy, B. S. (1998). Chemo-preventive effect of Squalene on colon cancer. Carcinogenesis, 19: 287-290. 
[17] Ishida, H., Suzuno, H., Sugiyama, N., Innami, S., Tadokoro, T. and Maekawa, A. (2000). Nutritional evaluation of chemical component of leaves stalks and stems of sweet potatoes (Ipomoea batatas poir). Food Chemistry, 68: 359-367.

[18] Gonzalez, L. C., Pinilla, L., Tena-Sempere, M., Bellido, C., Aguilar, E. (2001). Effects of systemic blockade of nitric oxide synthases on pulsatilelh, prolactin, and GH secretion in adult male rats. Hormone Research, 55(5): 229-235.

[19] Barnes, M. J., Lapanowski, K., Rafols, J. A., Lawson, D. M., Dunbar, J. C. (2002). Chronic nitric oxide deficiency is associated with altered leutinizing hormone and folliclestimulating hormone release in ovariectomized rats. Experimental Biology and Medicine, 227(9): 817-22.

[20] Miraglia, E., De Angelis, F., Gazzano, E., Hassanpour, H., Bertagna, A. (2011).Nitric oxide stimulates human sperm motility via activation of the cyclic GMP/protein kinase $\mathrm{G}$ signaling pathway. Reproduction, 141(1): 47-54.

[21] Topo, E., Soricelli, A., D'Aniello, A., Ronsini, S., D'Aniello, G. (2009). The role and molecular mechanism of D-aspartic acid in the release and synthesis of LH and testosterone in humans and rats. Reproductive Biology and Endocrinology, 27: 7:120
[22] Aiello, F., Garofalo, A., Aloisi, A. M., Lamponi, S., Magnani, A., Petroni, A. (2013). Synthesis of esters of androgens with unsaturated fatty acids for androgen requiring therapy. Journal of Endocrinological Investigation, 36(6): 390-5.

[23] Kobayashi, M., Hori, T., Kawakami, E. (2013). Changes in prostaglandin E2 levels in seminal plasma during ejaculation and the effect of exogenousprostaglandinE2onsemen volume in the dog. Journal of Veterinary Medical Science, 75(9): 1249-52.

[24] Robb, G. W., Amann, R. P. and Killian, O. J. (1978). Daily sperm production and epididymal sperm reserves of pubertal and adult rats. Journal of Reproduction and Fertility. 54: 103107.

[25] Turner, T. T., Hartmann, P. K., and Howards, S. S. (1977). In vivo sodium, potassium and sperm concentrations in the rat epididymis. Fertility and Sterility, 28: 191-194.

[26] Ward, E. M. (2009). Expect the Best: Your Guide To Healthy Eating Before, During and After Pregnancy. Hoboken, NJ: John Wiley \& Sons, Inc. 